\title{
MODERN SPACE POLICY OF UKRAINE AND THE REALITY OF JOINING THE EUROPEAN SPACE AGENCY
}

Today, the question of the probability of Ukraine's accession to the European Space Agency is becoming quite popular. However, can we observe a real basis for this? Or will it remain at the level of planning and discussion without further implementation? The State Space Agency of Ukraine, and the European Space Agency, are currently working on a roadmap to address this issue. Thus, in two or three years we will have a concrete procedure, and according to the current head of the State Space Agency of Ukraine, we will have the opportunity to join the European Space Agency. But, on the other hand, many reasons contradict the reality of such plans, namely: non-compliance of the State Space Agency of Ukraine with many criteria, inadequate level of legal regulation in space, imperfect and not updated under modern forms of government in space, etc.

An action plan for Ukraine's integration into the European Space Agency of Ukraine, aimed at implementing all components of European Space Agency membership, namely the following tasks: ensuring the negotiation process with European Space Agency to expand cooperation at this stage; building the image of Ukraine as an active partner of European Space Agency, the EU, and the Member States and associated with European Space Agency in the implementation of projects in the field of space activities; approximation of Ukrainian and EU legislation in the area of space activities and project implementation procedures; preparation for the conclusion of the Agreement of the state cooperating with European Space Agency; preparation for Ukraine's membership in European Space Agency. Among the key priorities of long-term cooperation with European partners, experts highlight the cooperation in the field of Global Navigation Satellite System (GNSS) in the framework of the pan-European global navigation satellite system EGNOS/Galileo, in the field of global monitoring for security and environment, and in particular in within the GMES project, as well as in the field of remote sensing of the Earth (remote sensing).

This paper will explore how real this is and how ready Ukraine is to join the European Space Agency. After all, Ukraine's accession to European Space Agency will give impetus to the development of space science and technology in Ukraine, allow it to join leading European space missions, enable Ukrainian companies to participate in European Space Agency programs and projects, and Ukraine - to use the final products of these programs and projects.

Key words: space activities, public administration, national security, European Space Agency, State Space Agency of Ukraine. 
Inesa Kostenko,

Researcher

of the Scientific Research

Institute of State Building

and Local Government

of National Academy

of Law Sciences

of Ukraine,

Ph.D.

orcid.org/0000-0002-8784-5422

i.v.kostenko@karazin.ua

\section{Introduction}

The current rapid development of the space industry in the world leads to the increasing use of space technology in almost all spheres of economic and social activity of mankind. In the public policy of developed countries, research and development aimed at using space to solve socio-economic and security problems have long been a priority. Analyzing the basic problems of the functioning of the domestic space industry, V. Horbulin warns in his work "Space Strategy and Prospects for the Development of the Country" that further delays in developing a wellthought-out state-space strategy may not only lead to the loss of Ukraine's status as a space state but also threaten the prospects for further development. The rapid development of technology and the rapidity of processes taking place in space markets require decisive and consistent steps based on real opportunities and an understanding of one's own priorities. The construction of such steps is associated with difficulties of a fundamental nature due to the lack of a clear industrial and innovation policy by the state. However, delays in implementing change pose a real threat to the rapid collapse of space activities and cause new and unexpected problems in the political, social, and security spheres (Горбулін, 2020).

Unfortunately, today, Ukraine's space policy is at a low level of development, and systematic and coordinated measures are needed to overcome these problems.

It is important to understand the need for and importance of implementing systemic measures and an updated model of domestic space activities that would meet today's challenges. Our vision of the problem is to substantiate the main approaches to the development of state policy in the field of space activities and to borrow from the successful European experience. What is important today is not only setting specific and clear goals and priorities, outlining key competencies of space activities in Ukraine, but also the implementation of the action plan. Successful implementation of any measure requires updating administrative, legislative, and regulatory documents in the field of space activities. Insufficient efficiency of the state space management system in Ukraine and imperfection of the current legal framework are the main reasons for 
the lack of involvement of the private sector and international investors in participating in global space activities and the production of rocket and space technology for the world market. Failure to implement strategic projects launched in previous years and the lack of new projects leads to an aging production and research base of space activities. The solution to these problems requires the application of a set of measures, including the introduction of a new management mechanism, strategic planning, and consistent scientific and technical policy based on a modern software approach. It is for this purpose that the National Targeted Scientific and Technical Space Program of Ukraine for 2021-2025 (hereinafter - the Program) was created ${ }^{1}$.

According to the program, there are currently three possible options in Ukraine to ensure the realization of the state's interests in the field of space activities. In the first case, while maintaining the existing approaches to the state management of space activities, the rapid collapse of space activities and the lack of a national system of remote sensing of the Earth are likely. If the state performs a purely regulatory function, and space activities are carried out on a commercial basis only concerning attractive space technologies for the world market, it will lead to the loss of some technologies in the technological chain of space rocket technology. The third, most optimal option is the development of own competencies in strategically important areas, attracting private companies and international investment together with financial support from the state, which will lead to the development of innovative technologies and economic efficiency in space (Кабінет Міністрів України, 2021b).

To implement the most optimal option to ensure the realization of the interests of the state in the field of space activities, the Program identifies the following areas of development: conducting space activities in the interests of national security and defense; creation of space observation systems of the Earth and their components; introduction of space technologies into the market of services; creation of rocket and space technology; basic and applied research in the field of space activities; legal, scientific-methodical, and informational support of the program activities (Міністерство з питань стратегічних галузей промисловості України, 2021).

Therefore, it is important to analyze the provisions of the regulatory framework in the field of space activities within the National Security Strategy of Ukraine and the National Targeted Scientific and Technical Space Program of Ukraine for 2021-2025, to further improve domestic space activities and deepen Ukraine's integration into the EU economy.

\section{Materials and methods}

The study analyzed the provisions of the National Security Strategy of Ukraine approved by the Decree of the President of Ukraine on September 14, 2020,

${ }^{1}$ On September 29, the Cabinet of Ministers of Ukraine supported the draft Law of Ukraine "On Approval of the National Targeted Scientific and Technical Space Program of Ukraine for 2021-2025", which was prepared by the Ministry of Strategy together with the State Space Agency of Ukraine (SCAU) in cooperation with all stakeholders (Cabinet of Ministers of Ukraine, 2021). 
No 392/2020; the analysis of the national target scientific and technical space program of Ukraine for 2021-2025 was carried out. In the process of writing the work, the author researched the scientific works of such scientists as V. Horbulin, A. Zayets, L. Soroka, V. Oleshchenko, I. Andrushko, A. Gurova, S. Negoda, O. Begly, O. Stelmakh. The following were used in the work: general scientific and special legal methods of scientific knowledge. Among the general scientific methods used are the methods of analysis and synthesis, deduction, induction, prediction, modeling, and analogy. Special methods of study and cognition were used: comparative law, historical law, technical and structural-functional methods. Forecasting was used to formulate proposals for solving the problems of current legislation. The comparative legal approach was used to study the European experience in the field of space activities and the possibility of implementing certain provisions in domestic practice.

\section{Results and discussions}

The development of a strategy for future space activities involves, first of all, an unbiased assessment of the current state of the industry and the identification of the most acute problems that have arisen over the past 20 years for various objective and subjective reasons. Significant achievements during the country's independence include the implementation of commercial projects "Sea Launch", "Land Launch", and "Dnieper", as well as the successful participation of Ukrainian companies in the European project "Vega", the American project "Antares", and the creation of spacecraft "Egypt Sat", as well as the spacecraft series "SICH". The measures planned in the space programs were aimed at reducing the number of UkrainianRussian projects, intensifying international cooperation, and a gradual transition to the realization of their own interests. The latter goal has not been achieved, although the corresponding task was provided for in the policy documents of recent years. The main reasons for this were inadequate funding for space programs (only $30 \%$ of what was planned), a lack of government procurement, and project disruptions. It should be noted that the main goals of space activities announced in recent years have not been achieved. In particular, the space industry has not become a driving force for high-tech economic development and the introduction of space technologies and the information obtained through them in the fields of public administration, national security and defense, resource control systems, and more. The main program goals, such as the creation of a national system of remote sensing of the Earth (remote sensing) and participation in international programs for the implementation of important scientific projects, have also not been met (Горбулін, 2020).

The Ukraine's "On State Regulation in the Sphere of Satellite Navigation" and the "On State Regulation in the Sphere of Remote Sensing of the Earth" are systemically important today. Prospects for the development of national activities in the field of remote sensing and satellite navigation determine the introduction into national space law of new concepts and terms: aerospace object remote sensing, remote sensing, remote sensing activities, operator of aerospace remote sensing, 
space systems for remote sensing of the Earth, the user of data for remote sensing of the Earth, the national market of space information technologies, satellite navigation, satellite communication, global navigation satellite systems, national satellite communication (Шемшученко, Семеняка, 2019).

Analyzing the provisions of the draft law "On state regulation in the field of satellite navigation", we see some gaps, namely: inconsistency of the title of the project with its content, as the draft regulates the basics of satellite navigation, and the title on state regulation in this area. Another disadvantage is the lack of a definition of the meaning of the term "satellite navigation". There is only a definition of auxiliary concepts for this term ("satellite navigation aids", "satellite navigation objects", "satellite navigation subjects", etc.), which complicates understanding projects. In addition, the draft does not correlate its provisions with the provisions of the Law of Ukraine "On Space Activities", as according to paragraph 4 of Part 1 of Art. 1, "global navigation satellite systems" means "space radio navigation systems", and according to paragraph 1 of Part 1 of Art. 1, "functional addition", "satellite or terrestrial information and telecommunications system", which indicates the presence of satellite navigation in the space element. According to Art. 1 of the Law of Ukraine "On Space Activities", "objects of space activities (space technology)" are tangible objects of artificial origin, designed, manufactured, and operated both in outer space (space segment, space infrastructure) and on the Earth's surface (terrestrial infrastructure) to explore and use outer space. In addition, inaccuracies were found in Art. 2 of the draft, as the article states that relations in the field of satellite navigation are regulated by the Law of Ukraine "On Ratification of the Agreement on Cooperation in Civil Global Navigation Satellite System (GNSS) between Ukraine and the European Union, its Member States" (Свропейське Співтовариство, 2005), which focuses mainly on the European GNSS GALILEO, but on the territory of Ukraine are functionally available other GNSS, which were not specified in the project (Conclusion of the Main Scientific and Expert Department on the draft Law of Ukraine "On state regulation in the field of satellite navigation" (Кабінет Міністрів України, 2019)). In this case, when drafting the bill, it is necessary to use a comprehensive modern legal update of the space industry, taking into account the peculiarities of space activities and international and national space law. Inaccuracies are not acceptable in this case. It should be noted that the global navigation satellite systems, namely the creation of the European global satellite navigation system "Galileo" and the provision of navigation services, have been identified as priority cooperation programs in the European Union's Horizon 2020 program (Проскура, 2017). The main purpose of this program is to create satellite systems and related terrestrial infrastructure in Europe to monitor the Earth's surface and provide geographic information services that provide access to accurate data and information in the fields of the environment and security for citizens of Europe and other countries; applied space technologies, in particular launch technologies and rocket engine technologies (Утко-Масляник, 2018). 
Today, the issue of conducting activities in the field of remote sensing of the Earth remains unresolved at the legislative level. In particular, the regulation of the introduction and integrated use of remote sensing of the Earth to perform state tasks in monitoring emergencies, agro-industrial complexes, subsoil use, ecomonitoring, land and forest management, national security and defense; ensuring interdepartmental coordination and cooperation on the exchange and multi-purpose use of remote sensing data purchased at the expense of the budget; the creation and functioning of a single state system of archiving and access to remote sensing data of the Earth, as well as a system of control over their distribution (Order of the Cabinet of Ministers of Ukraine "On approval of the Concept of the draft Law of Ukraine "On state regulation in the field of remote sensing of the Earth" (Кабінет Міністрів України, 2013)). The concept of this bill was approved in 2013, and in 2018 the bill was approved by the State Regulatory Service of Ukraine (Decision of the State Regulatory Service of Ukraine "On approval of the draft regulatory act" from June 4, 2018 № 243 (Державна регуляторна служба України, 2019)). Today, following paragraph 131 of the Government's Priority Action Plan for 2021, approved by the order of the Cabinet of Ministers of Ukraine on March 24, 2021 № 276-p, the development and submission to the Cabinet of Ministers of Ukraine of the bill on state regulation in the field of remote sensing of the Earth remains on the list of tasks (Кабінет Міністрів України, 2021a). Adoption of the Law of Ukraine "On State Regulation in the Field of Remote Sensing of the Earth" can ensure the effective use of remote sensing data in the interests of the state. The use of information obtained from the spacecraft allows research to improve methods for forecasting wheat yields, precipitation monitoring, assessing the impact of geodynamic factors on the ecological condition of urban areas, oil and gas exploration on land, and comprehensive monitoring of Black and Azov waters. parameters of the optical technical means of remote sensing in flight. That is, information obtained from satellite systems, in particular by remote sensing of the earth, is extremely relevant and progressive (Проскура, 2017). For example, scientists have already developed a procedure for identifying fluctuations in the spatiotemporal distribution of neutral and charged particles by probe measurements with scientific equipment BMI on the spacecraft "Sich-2". The localization of volcanic eruptions and epicenters of earthquakes that originate and occur on the satellite route of the spacecraft, as well as the localization of the southern and northern auroral peaks in the Earth's ionosphere (Шувалов и др., 2013).

According to the Government's Priority Action Plan for 2021, approved by the Cabinet of Ministers of Ukraine on March 24, 2021 (№ 276-p), paragraph 133 states the need to develop and submit to the Cabinet of Ministers of Ukraine a bill on the transformation of state unitary enterprises in the space industry into joint-stock companies. Such corporatization, as the procedure of transforming state unitary enterprises into joint-stock companies, is not a means of privatization. Corporatization contributes to a change in the organizational and legal forms of the business entity, 
but it has no effect on the form of ownership. As a result of corporatization, the stateowned property is transferred to the established company. At the same time, the state has corporate rights to this company, as well as the ability to manage and receive dividends from it. The purpose of corporatization is the reorganization of the state enterprise, aimed at improving the efficiency of its activities as a result of improving the management system (Бондаренко та ін., 2020). The implementation of such rafters makes sense, because, in the context of European integration, the joint-stock form of entrepreneurship is a powerful means of building an economic system based on non-state forms of social responsibility. At the same time, the widespread development of joint-stock forms contributes to the assertion of the fair nature of the appropriation of means and results of production; namely, the alienation of the property of direct employees of enterprises is overcome (Семенюк, Харун, 2019). In the case of the transformation of state unitary enterprises in the space industry into joint-stock companies, we will receive an update on the economic system, the creation of an innovative environment, the destruction of non-working structures, and pave the way for important transformations.

The development of an action plan for Ukraine's integration into the European Space Agency, the ultimate goal of which is to determine Ukraine's full membership in it, is specified in the Government's Priority Action Plan for 2021 in paragraph 135 The Ministry of Strategy and Industry is responsible for the implementation and implementation of this step, and the plan for December 2021 should be adopted by the Cabinet of Ministers of Ukraine. According to the plan, the expected results state: "use of the EU's" space "potential in the interests of Ukraine's economy and security; access to the tender system of the European Space Agency and full participation in the implementation of large-scale European space projects and research programs; access to advanced European space technologies to further improve domestic rocket and space technology; deepening the process of Ukraine's integration into the EU economy and promoting Ukraine's political integration into the EU" (Кабінет Міністрів України, 2021a).

However, has Ukraine reached the level of becoming a full member of the European Space Agency today? In our opinion, today there is a movement towards the implementation of the space program in Ukraine, but many planned tasks have not been solved, and many inaccuracies and inconsistencies remain, such as the first Ukrainian geostationary telecommunications satellite "Lybid" or the long process of adopting the law state regulation in the field of remote sensing of the Earth. Thus, from year to year in the field of space activities, we see the results of planning work and a fairly low level of efficiency in the implementation. For example, in accordance with the Government's Priority Action Plan for 2021, approved by the order of the Cabinet of Ministers of Ukraine dated March 24, 2021 № 276-p № 134, states: "Elaboration of further implementation of the project to create the National Satellite Communication System "Lybid", in the column "Expected Results", states: "submitted to the Cabinet of Ministers of Ukraine 
relevant proposals"; and the deadline of November 2021, i. e., in November 2021, only certain proposals on the possibility or impossibility of deciding on the procedure for further implementation of the National Satellite Communication System "Lybid". It will be recalled that in 2007, the Cabinet of Ministers of Ukraine adopted Resolution № 696 "On Measures to Establish a National Satellite Communication System" (Кабінет Міністрів України, 2007) (hereinafter - NSSS), which provided for the creation of the first Ukrainian geostationary telecommunications satellite "Lybid". Now we are watching the creation of the space system "Sich-2-30", so according to the plan, in September 2021 was to adopt an act of the Cabinet of Ministers of Ukraine, and in December 2021, to submit to the Cabinet of Ministers of Ukraine a report on spacecraft launch. Responsible for this matter are the State Tax Administration, the Ministry of Finance, and the Ministry of Strategy and Industry. Inaccuracy in planning and low efficiency of work are two of the points that need to be improved if Ukraine continues to move towards European Space Agency. The planned activities on the development of space activities do not contain provisions on the development of a bill on the regulation of the extraction and use of space resources, the appropriation of space resources, and the protection of human rights to information in the field of space activities. For example, Luxembourg in 2017 passed a law defining the licensing of resources extracted in space, becoming the first European country to introduce a licensing procedure for space resources (Luxembourg Space Agency, 2019). In 2018, the Luxembourg Space Agency published a study on the possibilities of using space resources. In 2019, the European Space Agency published its Space Resources Strategy. In November 2020, the country's space agency, in partnership with European Space Agency, opened the European Space Resources Innovation Center (ESRIC) ${ }^{2}$. It is, therefore, necessary to establish new clarifications on the extraction and use of space resources. Such concepts should ensure, support, and coordinate space activities at the appropriate level.

In his study "Space Strategy and Prospects for Country Development", V. Horbulin notes the following steps: establishing an effective vertical management of space activities, particularly through the establishment of the Space Council under the President of Ukraine; and establishing at the highest level a system of coordination of all participants in space activities. Organization of work to ensure the result: the transition to the implementation of practical projects; determination of the range of competencies of space activity of Ukraine, which meets the requirements of demand and competitiveness; implementation of measures envisaged by space programs based on system projects; separation of functions of customers, performers, and users of products and services of space activities; harmonization strategic, tactical, and network planning; introduction of measures for systematic analysis of space activities. Establishment and growth of the internal market for space technologies and information; incorporation of services, information, and

\footnotetext{
${ }^{2}$ See: https://www.esric.lu/about-us.
} 
technologies into state and branch programs; training of qualified users; promotion of advanced space technologies in the civil sector and civilian technologies in the space industry. Coherence of the program and strategic documents with the European space strategy (as well as technical regulation of space activities); complementarity of national projects with European initiatives. Reforming the space industry: establishing innovative links in product development and production through the integration of scientific and industrial potential; ensuring equal conditions for private and public enterprises; and public investment in infrastructure and training. Promotion of scientific research and innovative developments in promising areas of space activity; advancement of space education; and dissemination of space knowledge. State support for scientific and technological projects aimed at infrastructure development and modernization as a factor in attracting foreign investment. Comprehensive update of space legislation of Ukraine: formation of a system of laws and bylaws on new market-oriented principles, which should be reflected in the content of framework laws (Law of Ukraine "On Space Activities") and acts of by-laws; the new edition must meet the modern conditions of organization and implementation of space activities, based on permanent government procurement and commercialization of activities (Горбулін, 2020).

\section{Conclusions}

The paper presents a theoretical generalization of some legal and organizational principles of state regulation in the field of space activities within the National Security Strategy of Ukraine, the National Targeted Scientific and Technical Space Program of Ukraine for 2021-2025, and the Government's Priority Action Plan for 2021. Their shortcomings are identified and solutions are provided.

\section{Bibliography:}

1. Бондаренко С., Поліщук А., Мосін М. Передумови корпоратизації та тенденції розвитку підприємств оборонно-промислового комплексу України. Journal of Scientific Papers "Social Development and Security”. 2020. Vol. 10. № 6. P. 107-118. URL: http:// www.paperssds.eu/index.php/JSPSDS/article/view/256/282.

2. Горбулін В. Космічна стратегія та перспективи розвитку країни. Вісник Національної академї наук України. 2020. № 2. C. 3-10. URL: http://dspace.nbuv.gov.ua/bitstream/ handle/123456789/169886/03-Gorbulin.pdf?\%20sequence=1.

3. Идентификация землетрясений по зондовым измерениям возмущений параметров ионосферной плазмы на КА «Сич-2» / В. Шувалов, Д. Лазученков, С. Носиков, Г. Кочубей. Космічна наука і технологія. 2013. Т. 19. № 5. C. 16-26. URL: https://www.mao.kiev.ua/biblio/ jscans/knit/2013-19/knit-2013-19-5-03-shuvalov.pdf.

4. Про затвердження плану пріоритетних дій Уряду на 2021 рік : Розпорядження Кабінету Міністрів України від 24 березня 2021 р. № 276-p / Кабінет Міністрів України. URL: https:// www.kmu.gov.ua/npas/pro-zatverdzhennya-planu-prioritetnih-dij-uryadu-na-2021-s240321.

5. Про заходи щодо створення національної супутникової системи зв'язку : Постанова Кабінету Міністрів України від 3 травня 2007 р. № 696 / Кабінет Міністрів України. URL: https://zakon.rada.gov.ua/laws/show/696-2007-n\#Text. 
6. Про схвалення Концепції Загальнодержавної цільової науково-технічної космічної програми України на 2021-2025 роки : Розпорядження Кабінету Міністрів України від 13 січня 2021 р. № 15-p / Кабінет Міністрів України. URL: https://zakon.rada.gov.ua/laws/ show/15-2021-p\#Text.

7. Про схвалення Концепції проекту Закону України «Про державне регулювання у сфері дистанційного зондування Землі» : Розпорядження Кабінету Міністрів України від 28 серпня 2013 р. № 657-p / Кабінет Міністрів України. URL: https://zakon.rada.gov.ua/laws/ show/657-2013-p\#Text.

8. Проект Закону про державне регулювання у сфері супутникової навігації від 29 березня 2019 р. № 10198 / Кабінет Міністрів України. URL: http://w1.c1.rada.gov.ua/pls/ zweb2/webproc4_1?pf3511=65772.

9. Проскура Г. Правовий режим дистанційного зондування Землі як джерела екологічної інформації. АЕРО-2017. Повітряне $і$ космічне право : матеріали Всеукраїнської конференції молодих учених і студентів, м. Київ, 23 листопада 2017 р. / Національний авіаційний університет. Тернопіль : Вектор, 2017. Т. 1. С. 151-153. URL: https:// er.nau.edu.ua/bitstream/NAU/31619/1/Проскура\%20Г.M..pdf.

10. Семенюк Ю., Харун О. Розвиток акціонерних товариств в Україні за умов євроінтеграції. Фінансові аспекти розвитку економіки Украӥни: теорія, методологія, практика : збірник наукових праць молодих вчених та студентів / ред. кол. : Н. Хрущ, Р. Квасницька, І. Форкун та ін. Хмельницький : ХНУ, 2019. Т. 1. С. 82-84.

11. Угода про співробітництво щодо цивільної глобальної навігаційної супутникової системи (ГНСС) між Європейським Співтовариством, його державами-членами та Україною : міжнародний документ від 1 грудня 2005 р. / Європейське Співтовариство. URL: https://zakon.rada.gov.ua/laws/show/994_751\#Text.

12. Уряд схвалив Загальнодержавну цільову науково-технічну космічну програму України на 2021-2025 роки / Міністерство з питань стратегічних галузей промисловості України. Урядовий портал. 29 вересня 2021 p. URL: https://www.kmu.gov.ua/news/uryadshvaliv-zagalnoderzhavnu-cilovu-naukovo-tehnichnu-kosmichnu-programu-ukrayini-na2021-2025-roki.

13. Утко-Масляник Ю. Правові засади співробітництва між Україною та Європейським Союзом у космічній сферi. Advanced Space Law. 2018. Vol. 2. P. 96-111. URL: http:// asljournal.org/journals/2018-2/ASL_vol_2_Utko-Maslyanik.pdf.

14. Шемшученко Ю., Семеняка В. Сучасний стан та необхідність реформування космічного законодавства України. Часопис Київського університету права. 2019. № 2. C. 9-16.

15. Щодо погодження проекту Закону України «Про державне регулювання у сфері дистанційного зондування Землі» : лист Державної регуляторної служби України від 21 жовтня 2019 р. / Державна регуляторна служба України. URL: http://www.drs.gov.ua/ wp-content/uploads/2019/10/10262.pdf.

16. Law of July 20th 2017 on the Exploration and Use of Space Resources / Luxembourg Space Agency. November 11, 2019. URL: https://space-agency.public.lu/en/agency/legalframework/law_space_resources_english_translation.html.

\section{References:}

1. Bondarenko, S., Polishchuk, A., Mosin, M. (2020). Peredumovy korporatyzatsii ta tendentsii rozvytku pidpryiemstv oboronno-promyslovoho kompleksu Ukrainy [Prerequisites for corporatization and trends of development of enterprises of the defense and industrial complex of Ukraine]. Journal of Scientific Papers "Social Development and Security", vol. 10, 
no. 6, pp. 107-118. URL: http://www.paperssds.eu/index.php/JSPSDS/article/view/256/282 [in Ukrainian].

2. Horbulin, V. (2020). Kosmichna stratehiia ta perspektyvy rozvytku krainy [Space strategy and development prospects of the country]. Visnyk Natsionalnoi akademii nauk Ukrainy, no. 2, pp. 3-10. URL: http://dspace.nbuv.gov.ua/bitstream/handle/123456789/169886/ 03-Gorbulin.pdf?\%20sequence=1 [in Ukrainian].

3. Shuvalov, V., Lazuchenkov, D., Nosikov, S., Kochubey, G. (2013). Identifikatsiya zemletryaseniy po zondovym izmereniyam vozmushcheniy parametrov ionosfernoy plazmy na KA "Sich-2" [Identification of earthquakes with the use of Sich-2 probe measurements of ionospheric plasma perturbations]. Kosmichna nauka i tekhnolohiia, vol. 19, no. 5, pp. 16-26. URL: https://www.mao.kiev.ua/biblio/jscans/knit/2013-19/knit-2013-19-5-03-shuvalov.pdf [in Russian].

4. Cabinet of Ministers of Ukraine (2021a). Pro zatverdzhennia planu priorytetnykh dii Uriadu na 2021 rik: Rozporiadzhennia Kabinetu Ministriv Ukrainy vid 24 bereznia 2021 r. № 276-p [On approval of the Government's priority action plan for 2021: Order of the Cabinet of Ministers of Ukraine of March 24, 2021 № 276-p]. URL: https://www.kmu.gov.ua/npas/prozatverdzhennya-planu-prioritetnih-dij-uryadu-na-2021-s240321 [in Ukrainian].

5. Cabinet of Ministers of Ukraine (2007). Pro zakhody shchodo stvorennia natsionalnoi suputnykovoi systemy zviazku: Postanova Kabinetu Ministriv Ukrainy vid 3 travnia $2007 \mathrm{r}$. № 696 [On measures to establish a national satellite communication system: Resolution of the Cabinet of Ministers of Ukraine of May 3, 2007 № 696]. URL: https://zakon.rada.gov.ua/laws/ show/696-2007-п\#Text [in Ukrainian].

6. Cabinet of Ministers of Ukraine (2021b). Pro skhvalennia Kontseptsii Zahalnoderzhavnoi tsilovoi naukovo-tekhnichnoi kosmichnoi prohramy Ukrainy na 2021-2025 roky: Rozporiadzhennia Kabinetu Ministriv Ukrainy vid 13 sichnia 2021 r. № 15-p [On approval of the Concept of the National Targeted Scientific and Technical Space Program of Ukraine for 2021-2025: Order of the Cabinet of Ministers of Ukraine of January 13, 2021 № 15-p]. URL: https://zakon.rada.gov.ua/laws/show/15-2021-p\#Text [in Ukrainian].

7. Cabinet of Ministers of Ukraine (2013). Pro skhvalennia Kontseptsii proektu Zakonu Ukrainy "Pro derzhavne rehuliuvannia u sferi dystantsiinoho zonduvannia Zemli": Rozporiadzhennia Kabinetu Ministriv Ukrainy vid 28 serpnia 2013 r. № 657-p [On approval of the Concept of the draft Law of Ukraine "On state regulation in the field of remote sensing of the Earth”: Order of the Cabinet of Ministers of Ukraine of August 28, 2013 № 657-p]. URL: https:// zakon.rada.gov.ua/laws/show/657-2013-p\#Text [in Ukrainian].

8. Cabinet of Ministers of Ukraine (2019). Proekt Zakonu pro derzhavne rehuliuvannia u sferi suputnykovoi navihatsii vid 29 bereznia 2019 r. № 10198 [Draft Law on State Regulation in the Sphere of Satellite Navigation of March 29, 2019 № 10198]. URL: http://w1.c1.rada.gov.ua/ pls/zweb2/webproc4_1?pf3511=65772 [in Ukrainian].

9. Proskura, H. (2017). Pravovyi rezhym dystantsiinoho zonduvannia Zemli yak dzherela ekolohichnoi informatsii [Legal regime of remote sensing of the Earth as a source of environmental information]. Materials of the All-Ukrainian conference of young students "AERO-2017. Povitriane i kosmichne pravo" (Kyiv, November 23, 2017) / National Aviation University. Ternopil: Vektor, vol. 1, pp. 151-153. URL: https://er.nau.edu.ua/bitstream/NAU/31619/1/ Проскура\%20Г.M..pdf [in Ukrainian].

10. Semeniuk, Yu., Kharun, O. (2019). Rozvytok aktsionernykh tovarystv v Ukraini za umov yevrointehratsii [Development of joint stock companies in Ukraine in the context of European integration]. Finansovi aspekty rozvytku ekonomiky Ukrainy: teoriia, metodolohiia, praktyka: zbirnyk naukovykh prats molodykh vchenykh ta studentiv / N. Khrushch, R. Kvasnytska, I. Forkun et al. (eds.). Khmelnytskyi : KhNU, vol. 1, pp. 82-84 [in Ukrainian]. 
11. European Community (2005). Uhoda pro spivrobitnytstvo shchodo tsyvilnoi hlobalnoi navihatsiinoi suputnykovoi systemy (HNSS) mizh Yevropeiskym Spivtovarystvom, yoho derzhavamy-chlenamy ta Ukrainoiu: mizhnarodnyi dokument vid 1 hrudnia 2005 r. [Agreement on Cooperation in the Civil Global Navigation Satellite System (GNSS) between the European Community, its Member States and Ukraine: International Document of 1 December 2005]. URL: https://zakon.rada.gov.ua/laws/show/994_751\#Text [in Ukrainian].

12. Ministry of Strategic Industries of Ukraine (2021). Uriad skhvalyv Zahalnoderzhavnu tsilovu naukovo-tekhnichnu kosmichnu prohramu Ukrainy na 2021-2025 roky [The Government has approved the National Targeted Scientific and Technical Space Program of Ukraine for 2021-2025]. Uriadovyi portal, September 29. URL: https://www.kmu.gov.ua/news/uryad-shvalivzagalnoderzhavnu-cilovu-naukovo-tehnichnu-kosmichnu-programu-ukrayini-na-2021-2025-roki [in Ukrainian].

13. Utko-Maslianyk, Yu. (2018). Pravovi zasady spivrobitnytstva mizh Ukrainoiu ta Yevropeiskym Soiuzom u kosmichnii sferi [Legal basis of cooperation between Ukraine and the European Union in the space sector]. Advanced Space Law, vol. 2, pp. 96-111. URL: http:// asljournal.org/journals/2018-2/ASL_vol_2_Utko-Maslyanik.pdf [in Ukrainian].

14. Shemshuchenko, Yu., Semeniaka, V. (2019). Suchasnyi stan ta neobkhidnist reformuvannia kosmichnoho zakonodavstva Ukrainy [The current state and the need to reform the space legislation of Ukraine]. Chasopys Kyivskoho universytetu prava, no. 2, pp. 9-16 [in Ukrainian].

15. State Regulatory Service of Ukraine (2019). Shchodo pohodzhennia proektu Zakonu Ukrainy "Pro derzhavne rehuliuvannia u sferi dystantsiinoho zonduvannia Zemli": lyst Derzhavnoi rehuliatornoi sluzhby Ukrainy vid 21 zhovtnia 2019 r. [Regarding the approval of the draft Law of Ukraine "On state regulation in the field of remote sensing of the Earth": a letter from the State Regulatory Service of Ukraine dated October 21, 2019]. URL: http://www.drs.gov.ua/wp-content/ uploads/2019/10/10262.pdf [in Ukrainian].

16. Luxembourg Space Agency (2019). Law of July 20th 2017 on the Exploration and Use of Space Resources. URL: https://space-agency.public.lu/en/agency/legal-framework/law_space_ resources_english_translation.html [in English].

\title{
СУЧАСНА КОСМІЧНА ПОЛІТИКА УКРАЇНИ ТА РЕАЛЬНІСТЬ ВСТУПУ ДО ЄВРОПЕЙСЬКОГО КОСМІЧНОГО АГЕНТСТВА
}

\author{
Інеса Костенко, \\ старша наукова співробітниця \\ Науково-дослідного інституту державного будівництва \\ та місцевого самоврядування \\ Національної академії правових наук України, \\ кандидат юридичних наук \\ orcid.org/0000-0002-8784-5422 \\ i.v.kostenko@karazin.ua
}

Сьогодні популярним стає питання про ймовірність вступу Украӥни до Свропейського космічного агентства. Однак чи маємо ми реальне підгрунтя для втілення такого наміру? Або ж ие залишиться на рівні планування й обговорення без подальшої реалізаиії? Державне космічне агентство Украӥни та Європейське космічне агентство зараз працюють над дорожньою картою для розв'язання иієї проблеми. Таким чином, через два-три роки в нас буде конкретна прочедура та ми матимемо можливість приєднатися до Європейського 
космічного агентства. 3 іншого боку, сьогодні є безліч фактів, які суперечать реалізаиіі вступу, зокрема: невідповідність Державного космічного агентства України багатьом критеріям, неналежний рівень правового регулювання у сфері космічної діяльності, не вдосконалена та не оновлена відповідно до вимог сучасності форма правового регулювання у сфері космічної діяльності тощо.

План дій щодо інтеграчії Украӥни до Європейського космічного агентства спрямований на реалізачію всіх компонентів членства в Свропейському космічному агентстві, зокрема: забезпечення переговорного процесу з ним щчодо розширення співпраці на сучасному етапі; формування іміджу України як активного партнера Свропейського космічного агентства, Європейського Союзу та держав-членів, пов'язаного з Європейським космічним агентством у реалізації проєктів у сфері космічної діяльності; наближення законодавства Украӥни до законодавства Свропейського Союзу у сфері космічної діяльності та проиедур реалізачії проєктів; підготовку до членства Украӥни в Європейському космічному агентстві та підписання Угоди про співпрачю Державного космічного агентства Украйни з Свропейським космічним агентством.

Серед ключових пріоритетів довгострокової співпращі з європейськими партнерами експерти виділяють співпраџю у сфері глобальної навігаиійної супутникової системи (GNSS) у межах загальноєвропейської глобальної навігаційної супутникової системи EGNOS/Galileo, y сфері глобального моніторингу з метою безпеки навколишнього середовища (зокрема, у межах проєкту GMES), а також у сфері дистанційного зондування Землі (дистанційного зондування).

У статті буде досліджуватися, наскільки Україна готова приєднатися до Європейського космічного агентства в межах сучасних вимог та наскільки ие реально. Адже вступ України до Європейського космічного агентства дасть поштовх розвитку космічної науки й техніки в Украӥні, сприятиме ї̈ приєднанню до провідних європейських космічних місій, дасть можливість украӥнським компаніям брати участь у програмах $і$ проєктах Європейського космічного агентства, а Украйні - використовувати кінцеву продукцію цих програм і проєктів.

Ключові слова: космічна діяльність, державне управління, національна безпека, Європейське космічне агентство, Державне космічне агентство України. 